\title{
Mecanismos de hidratación del yeso
}

\section{Mechanism of gypsum hydration}

\author{
PACHECO G., ESFM-Depto. de Ciencia de Materiales IPN \\ PORTILLA M., DEPg-Fac. de Química UNAM
}

MÉXICO

Fecha de recepción: $15-X-90$

\section{RESUMEN}

En el mecanismo de hidratación y deshidratación del yeso existe la hipótesis de que éste se efectúa por dos fenómenos simultáneos.

Este estudio intenta esclarecer estos fenómenos, empleando: cloruros como aceleradores o mezcla etanol-metanol como retardadores para efectuar el fraguado del yeso.

Se emplean muestras de yeso de origen natural mexicano $y$ hemihidrato preparado en laboratorio; se utilizan técnicas analíticas: MO, DRX, DTA, TG y DTG.

De acuerdo a los resultados obtenidos se puede deducir: que la formación del coloide depende de la acción de los agentes aceleradores o retardadores y que los cristales son consecuencia de la cantidad de hemihidrato formado.

\author{
$S U M M A R Y$ \\ There is an hypothesis that the mechanism of gypsum \\ hydration and dehydration is performed through two \\ simultaneous phenomena. \\ In this study we try to clear up this phenomenon using \\ chlorides as accelerators or a mixture of ethanol-methanol \\ as retarders to carry out the gypsum setting.
}

Natural mexican gypsum samples and a hemihydrate prepared in the laboratory are used. The following analytical techniques are used: MO, DRX, DTA, TG and DTG.

In agreement with the obtained results, it can be concluded: that colloid formation depends on the action of accelerators or retarders and the crystals are a consequence of the quantity of hemihydrate formed.

\section{INTRODUCCIÓN}

Lavoisier (1) y Le Chatelier (2) fueron los primeros investigadores en observar formación de coloides y cristales en el fenómeno de hidratación de hemihidrato de sulfato de calcio.

M. Baykoff (3), utilizando las viscosidades de mezclas de hemihidrato de sulfato de calcio aguaacelerador o retardador, reafirma la teoría de formación coloidal.

J. Troube (4) adicionando sales, ácidos orgánicos, acelera o retarda el fenómeno de hidratación.

H. A. Neville (5) corrobora estas hipótesis tratando de explicar el fenómeno por un mecanismo de adsorción liosorción y quimisorción.

\section{INTRODUCTION}

Lavoisier (1) and Le Chatelier (2) were the first researchers to observe formation of colloids and crystals in the hemihydrate hydration phenomenon of calcium sulphate.

M. Baykoff (3) reaffirms the theory of colloidal formation by using the viscosities of mixtures of calcium sulphate hemihydrate and wateraccelerator or retarder.

J. Troube (4) accelerates or retards the hydration phenomenon by adding salts, organic acids, etc.

H. A. Neville (5) corroborates this hypothesis trying to explain the phenomenon by a mechanism of adsorption, liosortion and chemisorption. 
ESQUEMA 1

Transformaciones de Sulfato de Calcio

\begin{tabular}{|c|c|}
\hline \multicolumn{2}{|c|}{ SULFATO DE CALCIO DIHIDRATADO } \\
\hline \multicolumn{2}{|c|}{$\begin{array}{l}\mathrm{CaSO}_{4} \cdot 2 \mathrm{H}_{2} \mathrm{O} \\
\text { (MONOCLINICO) }\end{array}$} \\
\hline $\begin{array}{l}\text { Deshidratación } \\
\text { probablemente } \\
\text { involucrado un } \\
\text { ordenamiento }\end{array}$ & $\begin{array}{l}\text { Recristalización sin } \\
\text { ordenamiento }\end{array}$ \\
\hline \multicolumn{2}{|c|}{$\begin{array}{l}\text { HEMIHIDRATO DE SULFATO DE CALCIO + AGUA } \\
\text { CaSO } 4 \cdot 1 / 2 \mathrm{H}_{2} \mathrm{O}+\text { Agua }\end{array}$} \\
\hline $\begin{array}{l}\text { Pérdida casi- } \\
\text { zeolítica de agua } \\
\text { de la red sin } \\
\text { cristalización }\end{array}$ & $\begin{array}{l}\text { Agua absorbida del } \\
\text { vapor, sin } \\
\text { recristalización. . } \\
\text { Reacción casi- } \\
\text { zeolítica }\end{array}$ \\
\hline \multicolumn{2}{|c|}{$\begin{array}{l}\text { SULFATO DE CALCIO SOLUBLE } \\
\text { CaSO }_{4} \text { (Hexagonal) }\end{array}$} \\
\hline & $\begin{array}{l}\text { Reacción que } \\
\text { puede ocurrir a } \\
\text { temperatura } \\
\text { ambiente }\end{array}$ \\
\hline \multicolumn{2}{|c|}{$\begin{array}{l}\text { SULFATO DE CALCIO INSOLUBLE } \\
\text { CaSO }_{4} \text { (Ortorrómbica) }\end{array}$} \\
\hline
\end{tabular}

Aplicando técnicas selectivas de análisis como es el MEB, M. J. Ridge y J. Beretka (6) observan deformaciones intercristalinas en los fenómenos de hidratación del hemidrato postulando las transformaciones cristalográficas que se presentan en el esquema 1.

- Los autores definen los términos zeolítica y casi-zeolítica en relación al fenómeno de deshidratación lenta, la cual es función de la presión ejercida.

En el primero la presión baja continuamente influyendo en el estado cristalino y en el segundo caso esta presión decrece evitando la recristalización.

El hemihidrato del sulfato de calcio no recristaliza durante la hidratación produciéndose el fenómeno "casi-zeolítico".

La cristalografía del hemidrato es compleja y ha sido estudiada por Florke (10) quien todavía no esclarece totalmente y supone por observaciones macroscópicas en el hemidrato una morfología rombohédrica.

Diferentes autores han tratado de dilucidar sobre la cristalografía de los hidratos de sulfato de calcio (8), (9) y (10).
DIAGRAM 1

Calcium sulphate transformations

CALCIUM SULPHATE

$\mathrm{CaSO}_{4} \cdot 2 \mathrm{H}_{2} \mathrm{O}$

(MONOCLINIC)

\begin{tabular}{|c|c|}
\hline $\begin{array}{l}\text { Dehydration } \\
\text { probably involving } \\
\text { topotaxy }\end{array}$ & $\begin{array}{l}\text { Recrystallization } \\
\text { without topotaxy }\end{array}$ \\
\hline \multicolumn{2}{|c|}{$\begin{array}{l}\text { CALCIUM SULPHATE HEMIHYDRATE } \\
\text { CaSO }_{4} \cdot 1 / 2 \mathrm{H}_{2} \mathrm{O}+\text { Water }\end{array}$} \\
\hline $\begin{array}{l}\text { Quasi-zeolitic loss } \\
\text { of water from } \\
\text { lattice without } \\
\text { recristallization }\end{array}$ & $\begin{array}{l}\text { Water absorbed } \\
\text { from vapour. } \\
\text { Without } \\
\text { recrystallization. } \\
\text { Quasi-zeolitic } \\
\text { reaction }\end{array}$ \\
\hline \multicolumn{2}{|c|}{$\begin{array}{l}\text { HEXAGONAL CALCIUM SULPHATE } \\
\mathrm{CaSO}_{4}\end{array}$} \\
\hline & $\begin{array}{l}\text { Transformation } \\
\text { may occur even at } \\
\text { room temperature }\end{array}$ \\
\hline
\end{tabular}

ORTHORHOMBIC CALCIUM SULPHATE $\mathrm{CaSO}_{4}$

Applying selective analysis techniques as the MEB, M. J. Ridge and J. Beretka (6) observe intercrystalline deformations of the hydration phenomena of the hemihydrate and explain the crystallographic transformations as follows:

- Flörke et al. define: "In zeolitic dehydration the decomposition pressure falls continuously and the solid residue undergoes no substantial crystallographic reorganization. Calcium sulphate hemihydrate does not recrystallize during gentle dehydration, but the decomposition pressure drops steeply near the end to the process which we have decided to refer to as quasi-zeolitic".

Different authors have attempted to elucidate the problem of crystallography on calcium sulphates hydrates $(8,9,10)$. 


\section{PARTE EXPERIMENTAL}

Se describe en detalle la preparación de las muestras provenientes del yacimiento mexicano y preparadas en el laboratorio, se utiliza agua destilada y desionizada para la hidratación, cloruro de potasio al 0,2 \% como acelerador y como retardador una mezcla de etanol $95 \%$ y metanol $5 \%$ (en volumen). La morfología fue observada por medio de un microscopio marca Zeiss a $8.000 \mathrm{X}$, adaptado con una cámara fotográfica.

La caracterización cristalográfica fue efectuada por difracción de rayos $X$ utilizando un difractómetro Phillips PN120 con un tubo de cobre. Para la determinación de DTA y TG se utilizó un termoanalizador DUPONT.

M-1 Yeso seco proveniente del Estado de Morelos el cual pasó por malla 200.

M-2 Mezcla de yeso original al cual se le agrega agua durante $5 \mathrm{~min}$. y se agita a $5 \mathrm{rpm}$.

M-3 Mezcla de yeso original al cual se le agrega cloruro de potasio como acelerador durante 5 min. y se agita a $5 \mathrm{rpm}$.

M-4 Mezcla de yeso original al cual se le agrega la mezcla de etanol-metanol como retardador durante $5 \mathrm{~min}$. y se agita a $5 \mathrm{rpm}$.

M-5 Se preparó en el laboratorio según Caspari (8) el hemihidrato de sulfato de calcio.

M-6 Se agraga agua al hemihidrato de calcio y posteriormente una mezcla de etanol metanol como retardador.

\section{RESULTADOS Y DISCUSION}

En la foto 1 perteneciente al $\mathrm{CaSO}_{4} \cdot 2 \mathrm{H}_{2} \mathrm{O}, \mathrm{M}-1$ se observa la morfología notándose cristales aislados o bien aglomerados; se perciben algunos en forma de agujàs. En la tabla 1 se presentan las reflesiones características $h, k, l$ y las intensidades relativas, éstas fueron comparadas con las reportadas por la ASTM-21-81 y las cuales corresponden a un sulfato de calcio dihidratado.

Con objeto de corroborar las moléculas de agua se determina dicha pérdida por medio de la TG y se calcula estequiométricamente, la cual se puede apreciar en la Fig. 1. Se efectúa un DTA y se determina su comportamiento teórico (en relación al $\mathrm{Al}_{2} \mathrm{O}_{3}$ ); se pueden observar los dos pasos del fenómeno de deshidratación: 10. la pérdida de 1 1/2 moléculas de agua y por último la $1 / 2$ molécula que resta a temperatura más elevada.

\section{EXPERIMENTAL PROCEDURE}

We describe in detail the preparation of samples from mexican beds and prepared in the laboratory. Distilled, disionized water is used for hydration, potassium chloride $0.2 \%$ as accelerator and retarder and a mixture of ethanol $95 \%$ and methanol $5 \%$ (in volume). Morphology was observed through a Zeiss microscope at $8.000 \mathrm{X}$, adapted to a photographic camera.

Crystallographic characterization was carried out by X-ray diffraction using a PW120 Phillips difractometer with a copper tube. A DUPONT thermoanalyzer, 990 model, was used for the DTA, DTG and TG determination.

\section{M-1 Dry gypsum from Morelos, passed through a} 200 mesh.

M-2 Mixture of the original gypsum to which water is added for a 5 minutes period, stirred at 5 rpm.

M-3 Mixture of the original gypsum to which potassium chloride, as accelerator, is added for a 5 minutes periods, stirred at $5 \mathrm{rpm}$.

M-4 Mixture of the original gypsum to which the ethanol-methanol mixture, as accelerator, is added for a 5 minutes periods, stirred at $5 \mathrm{rpm}$.

M-5 The calcium sulphate hemydrate is prepared in the laboratory, according to Caspari (8).

M-6 Water is added to the calcium hemydrate and later an ethanol-methanol mixture as retarder.

\section{RESULTS AND DISCUSSION}

Photograph 1 refers to $\mathrm{CaSO}_{4} \cdot 2 \mathrm{H}_{2} \mathrm{O}$. M-1 shows morphology with isolated or agglomerated crystals, some of them being needle-like form. In Table 1 we present the characteristic $h, k, l$, reflections and the relative intensities; these were compared with the ones reported by ASTM-21-81 corresponding to a dehydrated calcium sulphate.

In order to strengthen water molecuies, such a loss is determined by TG and calculated stoichiometrically, as shown in Figure 1. A DTA is carried out to determine its theoretical behaviour (in relation to $\mathrm{Al}_{2} \mathrm{O}_{3}$ ). The two steps of the dehydration phenomenon can be observed: 1st. The loss of 1 1/2 water molecule and later on the 1/2 remaining molecule to a higher temperature. 


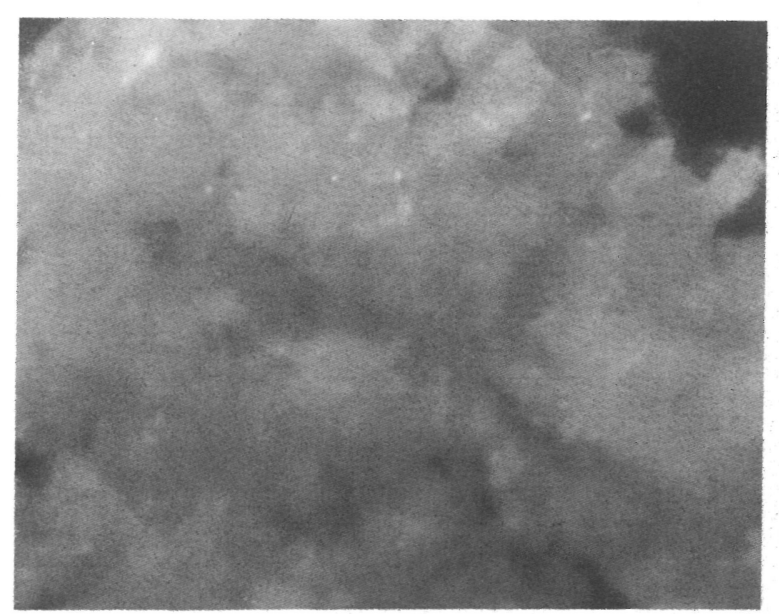

Foto 1. $-\mathrm{CaSO}_{4} \cdot 2 \mathrm{H}_{2} \mathrm{O}$ seco.

Foto 1.-Dry $\mathrm{CaSO}_{4} \cdot 2 \mathrm{H}_{2} \mathrm{O}$.

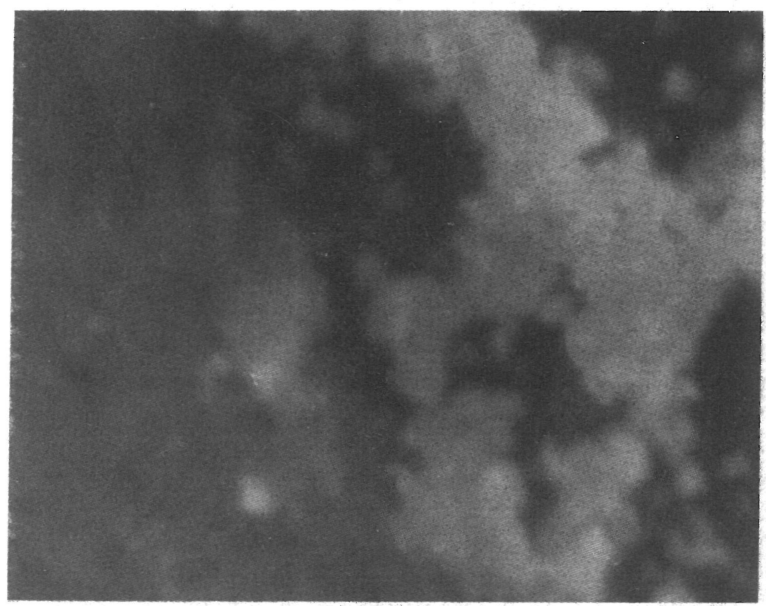

Foto 3. $-\mathrm{CaSO}_{4} \cdot 2 \mathrm{H}_{2} \mathrm{O}+\mathrm{H}_{2} \mathrm{O}+\mathrm{A}$ agitado a $5 \mathrm{rpm}$ por $5 \mathrm{~min}$.

Foto 3. $-\mathrm{CaSO}_{4} \cdot 2 \mathrm{H}_{2} \mathrm{O}+\mathrm{H}_{2} \mathrm{O}+\mathrm{A}$ stirred at $5 \mathrm{rpm}$ for $5 \mathrm{~min}$.

Simultáneamente a la TG se determina DTG que proporciona la velocidad a la cual se efectúan dichos cambios (Fig. 1).

En la foto 2 se muestra la morfología correspondiente a la $\mathrm{M}-2$, la cual es $\mathrm{CaSO}_{4}$. $2 \mathrm{H}_{2} \mathrm{O}+\mathrm{H}_{2} \mathrm{O}$ agitada $5 \mathrm{~min}$. a $5 \mathrm{rpm}$; en este caso los cristales bien formados observados en la $\mathrm{M}-1$ tienden a desaparecer notándose una pasta homogénea en forma de gel. Por medio de DRX se caracteriza la muestra de reflexiones $d, h, k, I$ pertenecientes al compuesto $\mathrm{CaSO}_{4} \cdot 5 \mathrm{H}_{2} \mathrm{O}$ (tabla 2); se puede señalar que existen variaciones en las reflexiones $d, h, k, I, 7,55$, 0,055 y $4,266 \AA$ en lo que se refiere a su intensidad.

La formación de este compuesto se corrobora por DTA y, posteriormente, por TG detectándose las cinco moléculas de agua

estequiométricamente (Fig. 2). Se completa por

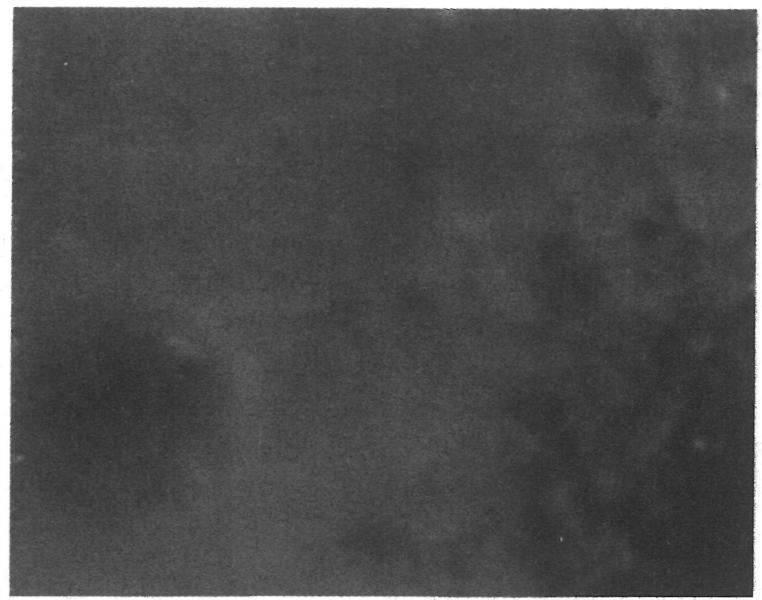

Foto 2. $-\mathrm{CaSO}_{4} \cdot 2 \mathrm{H}_{2} \mathrm{O}+\mathrm{H}_{2} \mathrm{O}$ agitado a $5 \mathrm{rpm}$ por $5 \mathrm{~min}$.

Foto 2. $-\mathrm{CaSO}_{4} \cdot 2 \mathrm{H}_{2} \mathrm{O}+\mathrm{H}_{2} \mathrm{O}$ stirred at $5 \mathrm{rpm}$ for $5 \mathrm{~min}$.

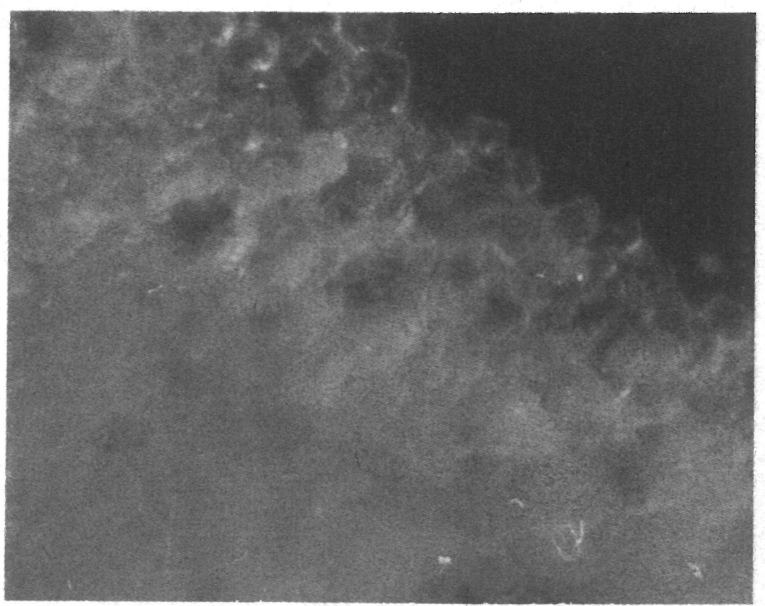

Foto 4. $-\mathrm{CaSO}_{4} \cdot 2 \mathrm{H}_{2} \mathrm{O}+\mathrm{H}_{2} \mathrm{O}+\mathrm{R}$ agitado a $5 \mathrm{rpm}$ por $5 \mathrm{~min}$.

Foto 4. - $\mathrm{CaSO}_{4} \cdot 2 \mathrm{H}_{2} \mathrm{O}+\mathrm{H}_{2} \mathrm{O}+\mathrm{R}$ stirred at $5 \mathrm{rpm}$ for $5 \mathrm{~min}$.

TG and DTG are determined simultaneously, supplying the rate at which the changes occur as shown in figure 1.

In photograph 2 we show the morphology corresponding to $\mathrm{M}-2$, being $\mathrm{CaSO}_{4} \cdot 2 \mathrm{H}_{2} \mathrm{O}+$ $\mathrm{H}_{2} \mathrm{O}$, stirred for $5 \mathrm{~min}$. at $5 \mathrm{rpm}$. In this case the well formed crystals observed in M-1 tend to disappear and a homogeneous paste in gel form is observed. The sample is characterized through a $D R X$, reflections $d, h, k, l$, belonging to the component $\mathrm{CaSO}_{4} \cdot 5 \mathrm{H}_{2}$ are shown in Table 2. It can be noticed that there are variations in reflections $d, h, k, I, 7.55,3.055$ and $4.266 \AA$ in relation to intensity.

Formation of this compound is corroborated by DTA and later on by TG, detecting the five water molecules stoichiometrically (see Fig 2). 
TABLAS 1 y 2 TABLES 1 and 2

Difracción de rayos $X$ de muestra de yeso ( $X$-ray diffraction of a gypsum sample)

\begin{tabular}{|c|c|c|c|}
\hline \multicolumn{2}{|c|}{ NATURAL SECO (NATURAL DRY) (*) } & \multicolumn{2}{|c|}{ NATURAL-AGUA (NATURAL-WATER) (**) } \\
\hline$d_{h k i}$ & $1 / t_{0}$ & $d_{\text {hkt }}$ & $1 / I_{0}$ \\
\hline 7.557 & 100 & 6.964 & 15 \\
\hline 4.266 & 90 & 5.569 & 35 \\
\hline 3.056 & 100 & 4.236 & 3 \\
\hline 2.855 & 25 & 3.622 & 8 \\
\hline 2.777 & 5 & 3.317 & 30 \\
\hline 2.672 & 30 & 2.895 & 100 \\
\hline 2.582 & 5 & 2.704 & 50 \\
\hline 2.533 & 5 & 2.623 & 5 \\
\hline 2.485 & 5 & 2.202 & 3 \\
\hline 2.437 & 8 & 2.081 & 10 \\
\hline 2.207 & 20 & 1.859 & 8 \\
\hline 2.076 & 8 & 1.802 & 25 \\
\hline 2.071 & 8 & 1.727 & 5 \\
\hline 1.981 & 4 & 1.725 & 5 \\
\hline 1.839 & 4 & 1.669 & 10 \\
\hline 1.821 & 10 & 1.657 & 10 \\
\hline 1.773 & 10 & 1.633 & 5 \\
\hline 1.656 & 2 & 1.628 & 5 \\
\hline 1.614 & 2 & 1.625 & 5 \\
\hline 1.581 & 2 & - & - \\
\hline
\end{tabular}

(*) Estas reflexiones fueron comparadas con las reportadas por la ASTM-21-816, las cuales corresponden a un: $\mathrm{CaSO}_{4} .2 \mathrm{H}_{2} \mathrm{O}$. (These reflections were compared with the ones reported by ASTM-21-816, corresponding to $\mathrm{CaSO}_{4} .2 \mathrm{H}_{2} \mathrm{O}$ ).

(**) Se observa una variación en las reflexiones $7,55,3,055$ y 4,26. (A variation in reflections $7.55,3.055$ and 4.26 is observed).

DTG la velocidad de deshidratación la cual se presenta en la Figura 2.

En la foto 3, la cual corresponde al $\mathrm{CaSO}_{4}$. $2 \mathrm{H}_{2} \mathrm{O}+0,2 \% \mathrm{KCL} \mathrm{M}-3$, se puede observar una formación de cristales en superficie al finalizar los 5 min. de reacción. Por difracción de rayos $X$ se caracteriza la muestra. En la tabla 3 se muestran las reflexiones $d, h, k, l$ obtenidas para la muestra; se puede observar que existe una mezcla de compuestos, ya que aparecen las reflexiones de la muestra $\mathrm{CaSO}_{4} \cdot 2 \mathrm{H}_{2} \mathrm{O}(\mathrm{M}-1)$.
Dehydration rate is completed by DTG, as shown in figure 2.

Photograph 3, corresponding to $\mathrm{CaSO}_{4} \cdot 2 \mathrm{H}_{2} \mathrm{O}+$ $0.2 \%-K C L M-3$, shows the formation of crystals on the surface at the end of the 5 min. reaction. The sample is characterized by XR diffraction and reflections $d, h, k, l$, obtained for the sample are shown in Table 3. It can be noticed that there is a mixture of compounds since the reflections of the sample $\mathrm{CaSO}_{4} \cdot 2 \mathrm{H}_{2} \mathrm{O}(\mathrm{M}-1)$ appear; It is worth 
Cabe señalar que las reillexiones $d, h, k, 1,3.743$, $2,390,2,065,1,983,1,890,1,804,1,773,1,617$ y $1,361 \AA$ aparecen con una intensidad mayor (10-15) respecto a la muestra original.

En la Figura 3 se muestran las deshidrataciones por DTA y el tipo de moléculas de agua presente (estructural o solamente absorbida en superficie). Esto se corrobora por TG y DTG, lo cual se representa en la Figura 3.

En la foto 4 se observa la formación de cristales y geles produto de la reacción de la $\mathrm{M}-4 \mathrm{CaSO}_{4}$. $2 \mathrm{H}_{2} \mathrm{O}+$ mezcla $\mathrm{C}_{2} \mathrm{H}_{5} \mathrm{OH} 95 \%+\mathrm{CH}_{3} \mathrm{OH} 5 \%$. Es interesante señalar que la formación de microcristales es a espensas del gel y que se efectúa en forma lenta.

En la tabla 4 se presentan las $d, h, k, 1$ características obienidas para esta muestra. Se puede mencionar que como en el caso de la M-3 las reflexiones d, h, k, I, 3,743, 2,390, 2,065, $1,383,1,890,1,773,1,617$ y $1,361 \AA$ aparecen con una intensidad mayor que la muestra original.

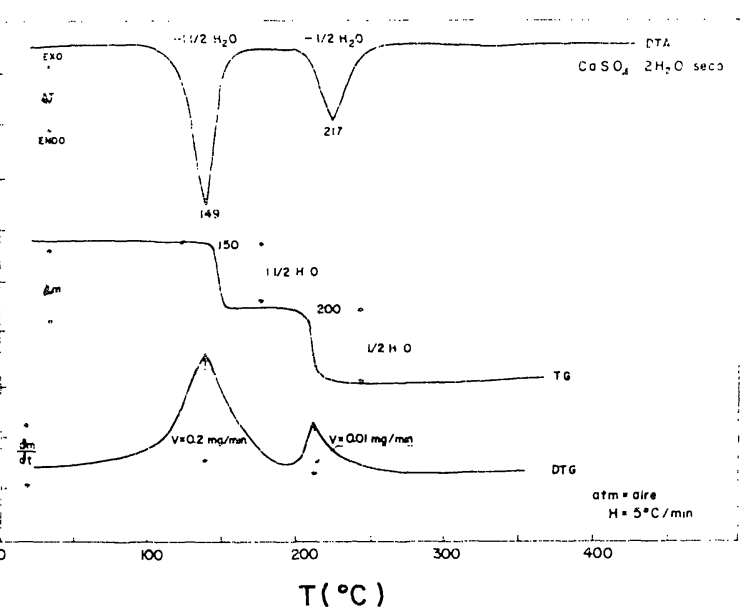

Fig. 1

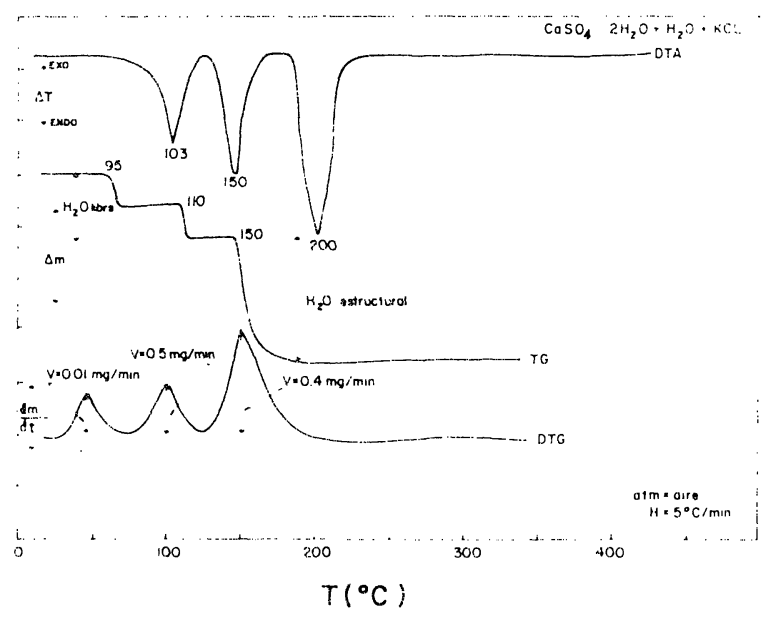

Fig. 3 noticing that reflections $d, h, k, !, 3.743,2.390$, $2.065,1.983,1.890,1.804,1.773,1617$ and 1.361 $\AA$ happen to have a higher intensity $(10-15)$ in relation to the original sample.

In figure 3 we show dehydrations by DTA and the kind of water moiecules present (structural or merely absorbed in the surface); this is corroborated by TG and DTG, as shown in figure 3 .

Figure 4 shows the formation of crystals and gels resulting irom the reaction of the $\mathrm{M}-4 \mathrm{CaSO}_{4}$. $2 \mathrm{H}_{2} \mathrm{O}+\mathrm{C}_{2} \mathrm{H}_{5} \mathrm{OH} 95 \%+\mathrm{CH}_{3} \mathrm{OH} 5 \%$ mixture. it is interesting so point out that the formation of microcrysials is at the expenses of the gel and takes place in a slow way.

In table 4 we present $d, h, k, l$, characteristics obtained for this sample. If can be mentioned that in the same way as in $M-3$, refiections $d, i n, k, i$, $3.743,2.390,2.065,1.983,1.890,1.804,1.773$, $\$ .617$ and $1.361 \AA$ have a higher intensity than the original sample.

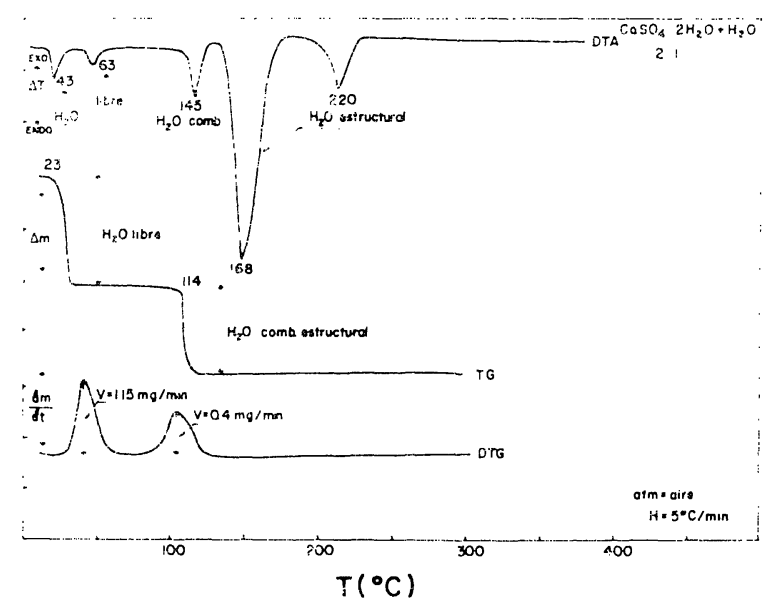

Fig. 2

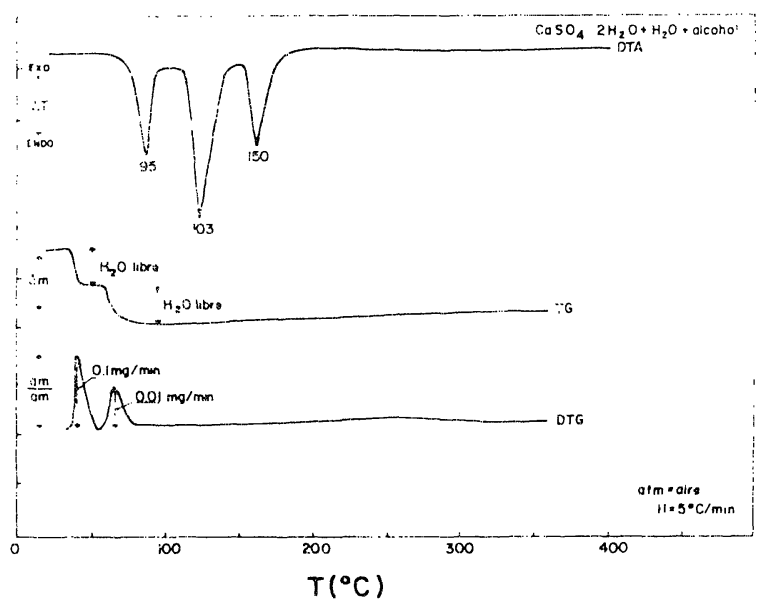

Fig. 4 
TABLAS 3 y 4 TABLES 3 and 4

Difracción de rayos $X$ de yeso + acelerador y yeso + retardador

( $X$ ray diffraction of gypsum + retarder and gypsum + retarder)

\begin{tabular}{|c|c|c|c|}
\hline \multicolumn{2}{|c|}{ NATURAL SECO (NATURAL DRY) (*) } & \multicolumn{2}{|c|}{ NATURAL-AGUA (NATURAL-WATER) (**) } \\
\hline$d_{\text {hkl }}$ & $1 / I_{0}$ & $d_{\text {hkl }}$ & $1 / I_{0}$ \\
\hline 7.493 & 100 & 7.461 & 100 \\
\hline 4.217 & 100 & 4.206 & 100 \\
\hline 3.743 & 95 & 3.735 & 100 \\
\hline 3.025 & 100 & 3.025 & 100 \\
\hline 2.855 & 25 & 2.851 & 25 \\
\hline 2.769 & 3 & 2.769 & 3 \\
\hline 2.668 & 20 & 2.664 & 20 \\
\hline 2.575 & 15 & 2.575 & 15 \\
\hline 2.475 & 3 & 2.474 & 3 \\
\hline 2.443 & 8 & 2.437 & 3 \\
\hline 2.390 & 2 & 2.380 & 3 \\
\hline 2.202 & 15 & 2.201 & 20 \\
\hline 2.065 & 15 & 2.067 & 15 \\
\hline 1.983 & 25 & 1.981 & 7 \\
\hline 1.890 & 25 & 1.890 & 30 \\
\hline 1.804 & 20 & 1.805 & 20 \\
\hline 1.773 & 15 & 1.771 & 15 \\
\hline 1.617 & 10 & 1.614 & 10 \\
\hline 1.361 & 10 & 1.361 & - \\
\hline
\end{tabular}

(*) Estas reflexiones fueron comparadas con las reportadas por la ASTM-21-816, las cuales corresponden a un: $\mathrm{CaSO}_{4} .2 \mathrm{H}_{2} \mathrm{O}$. (These reflections were compared with the ones reported by ASTM-21-816, corresponding to $\mathrm{CaSO}_{4} .2 \mathrm{H}_{2} \mathrm{O}$ ).

("*) Se observa una variación en las reflexiones $7,55,3,055$ y 4,26. (A variation in reflections $7.55,3.055$ and 4.26 is observed).

En la Figura 4 se muestra el DTA obtenido observándose que con el retardador aparece el agua libre, y a $103^{\circ} \mathrm{C}$ y $150^{\circ} \mathrm{C}$ se presentan las deshidrataciones de la molécula $\mathrm{CaSO}_{4} \cdot 2 \mathrm{H}_{2} \mathrm{O}$.

Por TG se confirman la cantidad de moles de agua absorbida en superficie y combinada determinándose a $95^{\circ} \mathrm{C}$ la temperatura inicial de deshidratación, completándose la observación por DTG (Fig. 4).

En la foto 5 , la cual corresponde a la muestra M-5 y que es: $\mathrm{CaSO}_{4} \cdot 1 / 2 \mathrm{H}_{2} \mathrm{O}$ hemihidrato
Figure 4 shows the obtained DTA and it can be noticed that with the use of the retarder the water is free and at $103^{\circ} \mathrm{C}$ and $150^{\circ} \mathrm{C}$ dehydration of the $\mathrm{CaSO}_{4} \cdot 2 \mathrm{H}_{2} \mathrm{O}$ molecule occurs.

The quantity of water moles absorded and combined on the surface is confirmed by TG, determining the initial dehydration temperature at $95^{\circ} \mathrm{C}$ (see Fig. 4). Observation is completed by DTG (see Fig. 4).

In photograph 5, corresponding to sample $\mathrm{M}-5$ : $\mathrm{CaSO}_{4} \cdot 1 / 2 \mathrm{H}_{2} \mathrm{O}$ hemydrate prepared in the 
preparado en el laboratorio, se observan por microscopio óptico dos formas cristalinas diferentes, las cuales fueron identificadas por CAX y corresponden al hemihidrato de calcio $\mathrm{CaSO}_{4} \cdot 1 / 2 \mathrm{H}_{2} \mathrm{O}$ y a la anhidrita soluble $\mathrm{CaSO}_{4}$.

En la foto $6, y$ perieneciente al $\mathrm{CaSO}_{4} \cdot 1 / 2 \mathrm{H}_{2} \mathrm{O}$ M-6 hemihidrato de calcio preparado en el laboratorio e hidratado posteriormente, se observa que el agua penetra con dificultad obteniéndose una capa delgada de gel; dado que el material no es cristalino no se caracterizó por DRX.

En las fotos 7 y 8 , las cuales pertenecen a las muestras de $\mathrm{CaSO}_{4} \cdot 1 / 2 \mathrm{H}_{2} \mathrm{O}+0,2 \mathrm{KCL} M-7 \mathrm{y}$ $\mathrm{CaSO}_{4} \cdot 1 / 2 \mathrm{H}_{2} \mathrm{O}+$ mezcla $\left(\mathrm{C}_{2} \mathrm{H}_{5} \mathrm{OH}+\mathrm{CH}_{3} \mathrm{OH}\right)$, se observa que en el caso del cloruro de potasio hay una formación del gel y cambios en los microcristales, mientras que en el caso de la mezcla de alcohol etílico y metílico el fenómeno

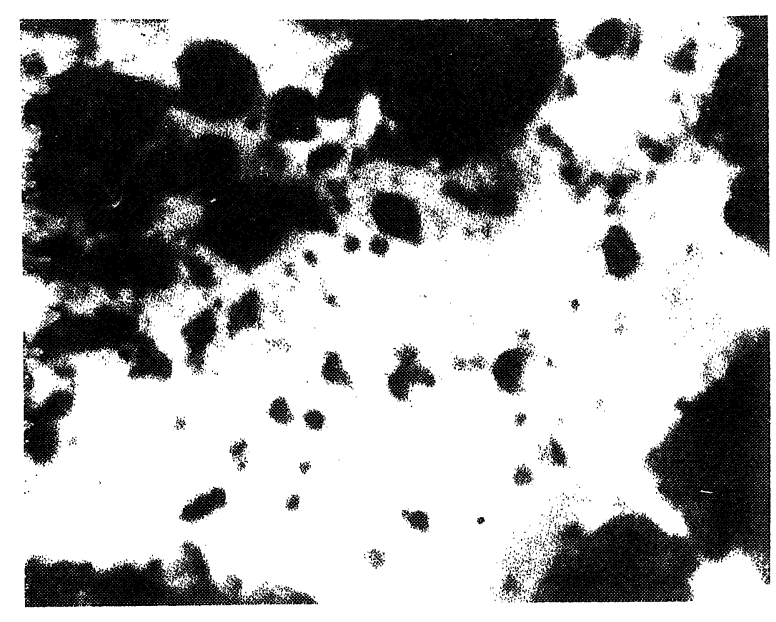

Foto 5 . $-\mathrm{CaSO}_{4} \cdot 1 / 2 \mathrm{H}_{2} \mathrm{O}$ seco.

Foto 5.-Dry $\mathrm{CaSO}_{4} \cdot 1 / 2 \mathrm{H}_{2} \mathrm{O}$.

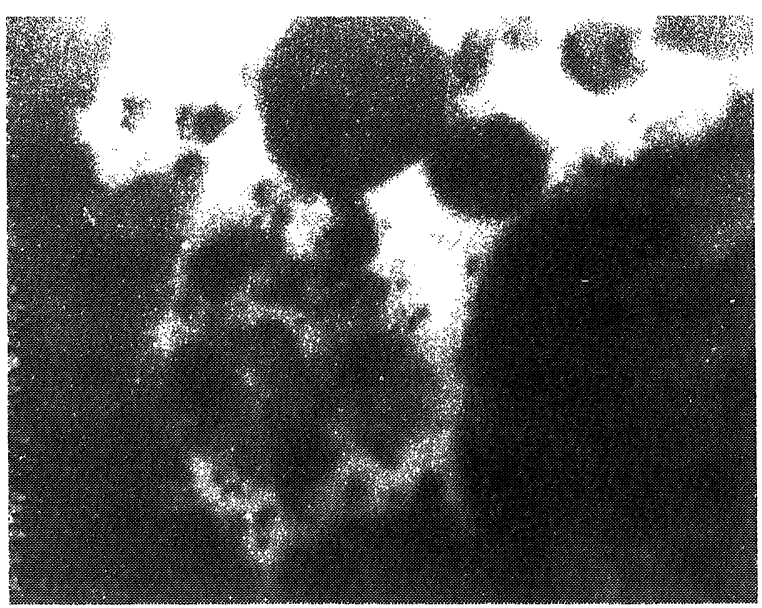

Foto 7.- $\mathrm{CaSO}_{4} \cdot 1 / 2 \mathrm{H}_{2} \mathrm{O}$ seco $+\mathrm{H}_{2} \mathrm{O}+\mathrm{A}$ agitado a $5 \mathrm{rpm}$ por $5 \mathrm{~min}$.

Foto 7-Dry CaSO $.1 / 2 \mathrm{H}_{2} \mathrm{O}+\mathrm{H}_{2} \mathrm{O}+\mathrm{A}$ stirred at $5 \mathrm{rpm}$ for $5 \mathrm{~min}$. laboratory, two different crystailine forms are observed through an optical microscope and identified by DRX. This corresponds to the $\mathrm{CaSO}_{4}$ - $1 / 2 \mathrm{H}_{2} \mathrm{O}$ calcium hemydrate and to the soluble anhydrate $\mathrm{CaSO}_{4}$.

Photograph 6 corresponding to $\mathrm{CaSO}_{4} \cdot 1 / 2 \mathrm{H}_{2} \mathrm{O}$ M-6 calcium hemihydrate prepared in the laboratory and hydrated afterwards, shows that water penetrates with difficulty, obtaining a thin gel layer due to the fact that the material is not crystailine, was not characterization by DRX.

Photographs 7 and 8 , beionging to $\mathrm{CaSO}_{4} \cdot 1 / 2$ $\mathrm{H}_{2} \mathrm{O}+0.2 \mathrm{KCL} \mathrm{M}-7$ and $\mathrm{CaSO}_{4} \cdot 1 / 2 \mathrm{H}_{2} \mathrm{O}+$ $\left(\mathrm{C}_{2} \mathrm{H}_{5} \mathrm{OH}+\mathrm{CH}_{3} \mathrm{OH}\right)$ mixture, shows that in the case of potassium chlorice there is a gel formation and changes in the microcrystals, while in the case of the ethylic and methylic alcohol mixture the hydration phenomenon increases. an

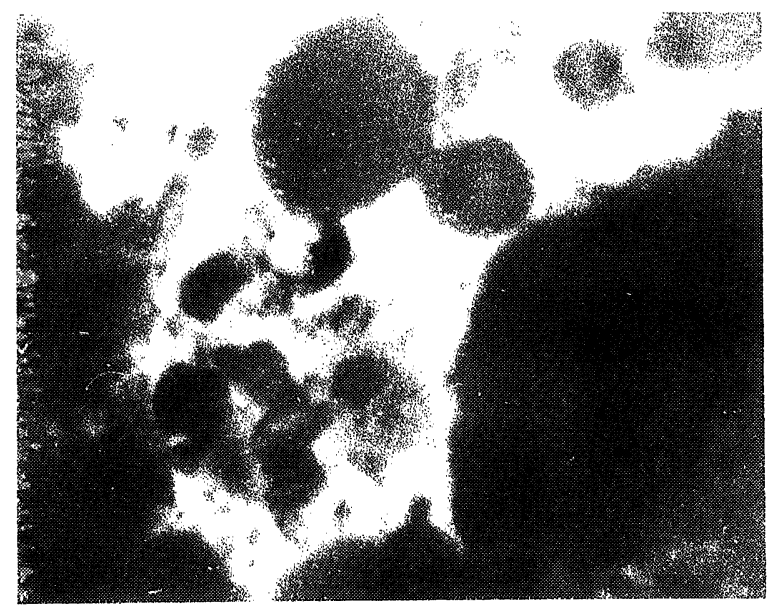

Foto 6 . - $\mathrm{CaSO}_{4} \cdot 1 / 2 \mathrm{H}_{2} \mathrm{O}$ seco $+\mathrm{H}_{2} \mathrm{O}$ agitado a $5 \mathrm{rpm}$ por $5 \mathrm{~min}$

Foto 6. - Dry $\mathrm{CaSO}_{4} \cdot 1 / 2 \mathrm{H}_{2} \mathrm{O}+\mathrm{H}_{2} \mathrm{O}$ stirred at $5 \mathrm{rpm}$ for $5 \mathrm{~min}$

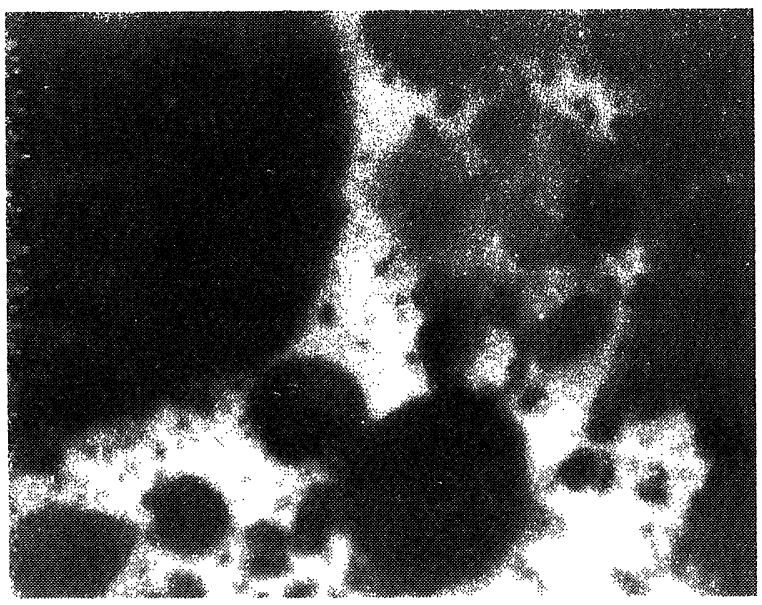

Foto 8. - $\mathrm{CaSO}_{4} \cdot 1 / 2 \mathrm{H}_{2} \mathrm{O}$ seco $+\mathrm{H}_{2} \mathrm{O}+\mathrm{R}$ agitado a $5 \mathrm{rpm}$ por $5 \mathrm{~min}$.

Foto 8.-Dry $\mathrm{CaSO}_{4} \cdot 1 / 2 \mathrm{H}_{2} \mathrm{O}+\mathrm{H}_{2} \mathrm{O}+\mathrm{R}$ stirred at $5 \mathrm{rpm}$ for $5 \mathrm{~min}$. 
de hidratación aumenta, se forma una opalescencia y en las orillas aparecen microcristales mezclados con gel.

\section{CONCLUSIONES}

Por medio de las observaciones en microscopio óptico y los resultados obtenidos en TG, DTA y DTG, se pudieron comparar los fenómenos de deshidratación en el sulfato de calcio dihidratado del Estado de Morelos, así como el hemihidrato de calcio preparado en el laboratorio $\mathrm{CaSO}_{4} \cdot 1 / 2$ $\mathrm{H}_{2} \mathrm{O}$.

Estos fenómenos se presentan en forma de geles y cristales, los cuales aumentan de tamaño conforme pasa el tiempo; este crecimiento es a partir de la parte gelificada. La adición de cationes como el potasio, en pequeñas cantidades, aceleran el fraguado y aumentan la gelación; este efecto tiene relación con la valencia del catión. La concentración del cloruro de potasio es importante ya que un exceso produce el efecto contrario.

La mezcla de etanol-metanol se utilizó para retardar el fenómeno. Se emplea como un agente dispersante, cooperando a concentrar y orientar las moléculas de agua en el hemihidrato (similar a la orientación de moléculas de jabón en una interfase aceite-agua).

La agitación mecánica es importante, ya que influye acelerando esta reacción. Los datos obtenidos por TG, DTA y DTG permiten calcular estequiométricamente el número de moléculas de agua presentes en estas reacciones.

\section{AGRADECIMIENTOS}

Los autores agradecen la valiosa colaboración del Ing. Salvador Medina por su trabajo fotográfico, y a la Sra. Irma Vigil de Aragón por la ayuda técnica en la elaboración del manuscrito. opalescence is formed and the borders are covered with a mixture of microcrysials and gel.

\section{CONCLUSIONS}

Through the optical microscopic observations and the results obtained by TG, DTA and DTG, the dehydration phenomena could be compared with the dehydrated calcium sulphate from Morelos, as well as the calcium hemihydrate $\mathrm{CaSO}_{4} \cdot 1 / 2 \mathrm{H}_{2} \mathrm{O}$ prepared in the laboratory.

These phenomena are present in gel form and crystals which have an increase in size when time passes. This growth sets up in the gelified part. The addition of cations such as small quantities of potassium, accelerates the setting and increases gelation; this effect is related with the cation valence. Potassium chloride concentration is important since an excess produces a counter effect.

An ethanol-methanol mixture was used to retard the phenomenon. It is used as a dispersing agent, helping the concentration and orientation of water molecules in the hemihydrate (similar to the orientation of soap molecules in the oil-water interphase).

Mechanical stirring is important since it influences the acceleration of this reaction. Data obtained by TG, DTA and DTG allow us to stoichiometrically calculate the number of water molecules present in these reactions.

\section{ACKNOWLEDGEMENTS}

The authors wish to thank Ing. Salvador Medina for his photographic work and Mrs. Irma Aragón for technical assistance.

\section{BIBLIOGRAFIA}

(1) A. L. Lavoisier, Deuvres compl, Vol. III, p. 122 (1965).

(2) H. Le Chatelier, "Crystalloids Against Colloids in the Theory of Cements", Transactions, Faraday Soc., Vol. 14, p. 8 (1919).

(3) M. Baykoff, Comptes Rendus, Vol. 182, p. 128 (1926).

(4) J. Troube, "Kolloide Vorgange beim benden des gipses Strukturen in gips", Kolloid Z, Vol. 25 p. 62, (1919).

(5) H. A. Neville, "Adsorption and Reaction I", Journal of Physical Chemistry, Vol. 30, p. 1.037 (1926).

(6) M. J. Ridge, J. Beretka, "Calcium Sulphate Hemydrate and its Hydration", Rev. Pure and Appl. Chim. 19, 17 (1960)

(7) Von K. Theisen, "Das Zusammenwisken von gipsentwass sserung und festigkeitsentwicklung von Portland Zement", Zementkalt-gips Int., Jahogung 36 (1983).

(8) Caspari W. A., Calcium Sulphate Hemihydrate and the Anhydrites - Crystallography Proceedings- Royal Society A., Vol. 155, pag. 41-48 (1936).

(9) De la Torre Aceves N., Bernechea Noriega J., Modificación del Hábito Cristalino del Sulfato de Calcio, México, D. F. (1974).

(10) Florke, O. W., News Lb. Miner Abh, 84, 189 (1952). 